Article

\title{
Assessment of the Constancy of Performance of Cementitious Adhesives for Ceramic Tiles: Analysis of the Test Results Commissioned by Polish Market Surveillance Authorities
}

\author{
Mateusz Łukasik, Bartosz Michałowski 1 and Jacek Michalak *(D) \\ Research and Development Center, Atlas sp. z o.o., 2, Kilinskiego St., 91-421 Lodz, Poland; \\ mateusz.lukasik@atlas.com.pl (M.Ł.); bmichalowski@atlas.com.pl (B.M.) \\ * Correspondence: jmichalak@atlas.com.pl
}

Received: 2 September 2020; Accepted: 18 September 2020; Published: 20 September 2020

check for updates

Featured Application: This work shows the complexity of the assessment and verification of the constancy of performance of construction products. The results contained therein may constitute the basis for considering the need to change the criteria for assessing cementitious adhesives for ceramic tiles. The results presented in the article may also be the basis for the possible verification of legal requirements for the control of a construction product, which are cementitious adhesives for ceramic tiles, connected with the potential difficulties in a detailed assessment.

\begin{abstract}
Assessment and verification of constancy of performance (AVCP) is a complex process. Without it, the manufacturer cannot mark the product with the Conformitè Europëenne (CE) marking and place it on the EU market. The verification of the correctness of the AVCP is carried out by market surveillance. In Poland, supervision authorities regularly check manufacturers by collecting construction products that exist on the market for inspection. Among the dry-mix mortars, adhesives for ceramic tiles (CTA) constitute an essential group. The requirements for CTAs are specified in EN 12004. According to the standard, the basic characteristics of cementitious CTAs are tensile adhesion strength and open time. The adhesion measurements are performed after various laboratory conditions tests. The study analyzes the results obtained for 129 samples of cementitious CTAs, collected between the years 2016 and 2019 from the market, and tested in notified laboratories at the request of Polish construction supervision authorities. Many tested products did not meet the threshold values, which resulted in removing them from the market. The paper discusses the complexity of the tensile adhesion strength measurement. The obtained test results are considered in various dimensions, including using the simple acceptance rule method when evaluating the results, which does not consider the measurement uncertainty.
\end{abstract}

Keywords: assessment and verification of constancy of performance (AVCP); market surveillance; ceramic tiles adhesive (CTA); cementitious ceramic tile adhesives; tensile adhesion strength

\section{Introduction}

The assessment and verification of constancy of performance (AVCP) is a harmonized system defining how to assess products and control the assessment results' constancy. AVCP is a complex and multi-dimensional process. In the European Union, the Construction Products Regulation (CPR) lays down harmonized rules for the marketing of construction products [1]. The document sets out also methods and criteria for assessing and expressing the performance of construction products, and the conditions for the use of the $\mathrm{CE}$ marking. The $\mathrm{CE}$ marking indicates that the performance of the 
product has been assessed, and that remains constant. The CE marking enables a construction product to be placed legally on the market in any EU country and then be traded on the EU's single market.

According to Regulation (EC) No 765/2008 [2], each member state must establish market surveillance authorities that will ensure compliance with this regulation's requirements in their countries. As a rule, if it is found that the product does not meet the criteria, i.e., the product does not meet the declared performance, actions must be taken immediately to adapt the product to the declared performance or to withdraw the product from the market. The type and manner of work should be related to the nature of the risk it creates. In Poland, the General Inspector of Building Control (GINB) is the central body of government administration in architectural and construction administration and construction supervision [3]. Construction supervision authorities (both GINB and voivodship inspectors of building control) perform tasks of market surveillance authorities, including inspections of construction products [4], in the field of CE-marked construction products. Construction product inspections are scheduled or ad hoc. They cover various tasks, including, among others, analysis of documentation and control tests of products performed at the request of construction supervision in notified laboratories. Due to the commonly performed tests of construction products commissioned by construction supervision authorities, the Polish market of construction products differs from other EU countries' construction product markets. The activities of construction supervisors are organized differently in the member states, and the role of construction supervision is understood differently [5].

Nowadays, dry-mix mortars prepared in specialized production plants (plaster, render, tile adhesive, grouts, waterproofing slurries, concrete protection and renovation, insulation and finishing systems, and others) are widely used in construction. Cementitious adhesives for laying ceramic tiles are an essential assortment group among ready-made dry-mix mortars. In 2018, the production of ceramic tiles in the world amounted to 13.099 billion $\mathrm{m}^{2}$, including 1.366 billion $\mathrm{m}^{2}$ in the EU countries, and consumption reached 12.818 billion $\mathrm{m}^{2}$ and 1.034 billion $\mathrm{m}^{2}$, respectively [6]. Assuming the average use of cementitious adhesives for ceramic tiles of $4 \mathrm{~kg} / \mathrm{m}^{2}$, this means the world production of tile adhesives is over 52 million tons, including just over 4 million tons in the EU countries.

Following the work carried out by CEN/TC 67/WG 3 in 2001, the European standard EN 12004: 2001 was established [7]. Since then, we can talk about the unification of requirements for CTAs at the European level. In Poland, the EN 12004 standard was introduced to the Polish standards set in 2002 as part of pre-accession activities aimed at the country's accession to the EU. However, only after Poland joined the EU on 1 May 2004 could Polish producers, on an equal footing with producers from other EU countries, take advantage of the opportunities provided by this standard. Previously, other requirements were in force in Poland, which additionally changed several times [8].

The EN 12004 standard with the requirements for CTAs had successive editions, i.e., EN 12004: 2001/A1:2002/AC:2002, EN 12004:2007, EN 12004:2007+A1:2012, and EN 12004-1:2017. However, the last version of the standard with the requirements for tile adhesives, published in the list of European harmonized standards [9], is EN 12004:2007+A1:2012 [10]. The next version of the standard published by CEN in 2017, EN 12004-1:2017 [11], has not yet been included in the list of harmonized standards published in the Official Journal of the European Union and is not the basis for the AVCP process. However, for the seven years, the CPR rules [1] are in force and the document used in the AVCP process of tile adhesives is a standard from the old legal order, i.e., from the time of Directive 89/106/EEC Construction products [12].

The EN 12004 standard, apart from cementitious adhesives, also applies to dispersion adhesives and adhesives based on reactive resins for ceramic tiles. It is worth mentioning that the EN 12004 standard divided cement-based adhesives (C) for ceramic tiles into two main classes (groups): with basic properties, marked as $\mathrm{C} 1$, and with enhanced parameters, marked as $\mathrm{C} 2$. Table 1 presents the requirements for cementitious adhesives for ceramic tiles following PN-EN 12004:2007+A1:2012 [10]. 
Table 1. Requirements for cementitious (C) adhesives for ceramic tiles (CTA) according to EN 12004:2007+A1:2012 [10].

\begin{tabular}{|c|c|c|}
\hline \multicolumn{3}{|c|}{ Fundamental Characteristics } \\
\hline Characteristics & Requirement & Test Method \\
\hline \multicolumn{3}{|c|}{ Normal setting adhesives (C1) } \\
\hline Initial tensile adhesion strength & $\geq 0.5 \mathrm{~N} / \mathrm{mm}^{2}$ & 8.2 of $\mathrm{EN} 1348$ \\
\hline $\begin{array}{l}\text { Tensile adhesion strength after } \\
\text { water immersion }\end{array}$ & $\geq 0.5 \mathrm{~N} / \mathrm{mm}^{2}$ & 8.3 of EN 1348 \\
\hline $\begin{array}{l}\text { Tensile adhesion strength after } \\
\text { heat ageing }\end{array}$ & $\geq 0.5 \mathrm{~N} / \mathrm{mm}^{2}$ & 8.4 of EN 1348 \\
\hline $\begin{array}{l}\text { Tensile adhesion strength after } \\
\text { freeze-thaw cycles }\end{array}$ & $\geq 0.5 \mathrm{~N} / \mathrm{mm}^{2}$ & 8.5 of EN 1348 \\
\hline $\begin{array}{l}\text { Open time: tensile adhesion } \\
\text { strength }\end{array}$ & $\geq 0.5 \mathrm{~N} / \mathrm{mm}^{2}$ & EN 1346 \\
\hline \multicolumn{3}{|c|}{ Fast setting adhesives (C1F) } \\
\hline Early tensile adhesion strength & $\geq 0.5 \mathrm{~N} / \mathrm{mm}^{2}$ & 8.2 of EN 1348 \\
\hline $\begin{array}{l}\text { Open time: tensile adhesion } \\
\text { strength }\end{array}$ & $\geq 0.5 \mathrm{~N} / \mathrm{mm}^{2}$ & EN 1346 \\
\hline All other requirements as for norm & 1 setting adhesives $(\mathrm{C} 1)$ & EN 1348 \\
\hline \multicolumn{3}{|c|}{ Optional characteristics } \\
\hline Characteristics & Requirement & Test Method \\
\hline \multicolumn{3}{|c|}{ Special characteristics } \\
\hline Slip & $\leq 0.5 \mathrm{~mm}$ & EN 1308 \\
\hline $\begin{array}{l}\text { Extended open time: tensile } \\
\text { adhesion strength }\end{array}$ & $\geq 0.5 \mathrm{~N} / \mathrm{mm}^{2}$ & EN 1346 \\
\hline $\begin{array}{l}\text { Deformable adhesive: transverse } \\
\text { deformation }\end{array}$ & $\geq 2.5 \mathrm{~mm}$ and $<5 \mathrm{~mm}$ & EN 12002 \\
\hline $\begin{array}{l}\text { Highly deformable adhesive: } \\
\text { transverse deformation }\end{array}$ & $\geq 5 \mathrm{~mm}$ & EN 12002 \\
\hline \multicolumn{3}{|c|}{ Additional characteristics (C2) } \\
\hline $\begin{array}{l}\text { High initial tensile adhesion } \\
\text { strength }\end{array}$ & $\geq 1 \mathrm{~N} / \mathrm{mm}^{2}$ & 8.2 of EN 1348 \\
\hline $\begin{array}{l}\text { High initial adhesion strength } \\
\text { after water immersion }\end{array}$ & $\geq 1 \mathrm{~N} / \mathrm{mm}^{2}$ & 8.3 of EN 1348 \\
\hline $\begin{array}{l}\text { High tensile adhesion strength } \\
\text { after heat ageing }\end{array}$ & $\geq 1 \mathrm{~N} / \mathrm{mm}^{2}$ & 8.4 of EN 1348 \\
\hline $\begin{array}{l}\text { High tensile adhesion strength } \\
\text { after freeze-thaw cycles }\end{array}$ & $\geq 1 \mathrm{~N} / \mathrm{mm}^{2}$ & 8.5 of EN 1348 \\
\hline
\end{tabular}

When discussing the requirements for cementitious adhesives for ceramic tiles, it is necessary to pay attention to the transverse deformability of adhesives. According to this requirement, there are two types of tile adhesives-S1 (deformable adhesives) and S2 (highly deformable adhesives).

CEN/TC 67/WG 3 experts, when creating the EN 12004 standard, adopted as the basic characteristics of cementitious adhesives for tiles adhesion strength and open time, i.e., the maximum time, after applying the adhesive, when the tiles can be embedded in the adhesive layer to obtain the required adhesion strength. The measurement of adhesion strength is performed after the mortar has been stored in various laboratory conditions, the task of which is to simulate the real conditions in which cement tile adhesives are used.

The key to the classification of cementitious adhesives for ceramic tiles is the determination of adhesion strength by the measurement of tensile strength. In this aspect, it is worth looking at the measurement methodology and its standardization. From a practical point of view, perhaps the most interesting for manufacturers of CTAs is the reproducibility of the results, i.e., the degree of 
agreement between the results obtained by different analysts in different laboratories using a given measurement procedure.

Felixberger [13] described the results of initial adhesion tests of seven cementitious adhesives to ceramic tiles, carried out in ten laboratories using two different test concrete slabs. As the first test concrete slab, each of the participating laboratories used a standard test concrete slab that meets the requirements of EN 1323:2007 [14]. The second concrete slab was purchased by the research organizer and delivered to all participating laboratories. The standard deviation of the measurement ranged from 15 to $20 \%$. As a result of the tests, the concrete slabs' influence on the value of the determined adhesion strength was found. For cementitious CTAs with a lower adhesion strength values, more considerable differences between individual measurements were made than for adhesives with higher adhesion strengths.

In 2007, the Romanian laboratory, notified in the EN 12004, initiated a project of interlaboratory measurements of the initial adhesion strength of cementitious CTAs. Nine laboratories, mainly Romanian, participated in the first round of the research (2008-2009). Five years later, 27 laboratories of research institutes and producers of tile adhesives from the following nine countries-Austria, Bulgaria, Croatia, Czech Republic, Germany, Poland, Portugal, Romania, and Slovenia-took part in the interlaboratory tests [15]. Proficiency tests/interlaboratory comparisons were organized according to uniform principles and under the requirements of EN ISO/IEC 17043 [16]. The initial adhesion of four different cementitious CTAs (C2FTE, C2TE, C2TES1, and C2TS1) was tested. All laboratories used the same concrete slabs for tests and the same ceramic tiles provided by the test organizer. According to the authors of the study, "over $90 \%$ of the test results obtained by participating laboratories can be described as" satisfactory "(having $(|z| \leq 2)$ under EN ISO/IEC 17043", while the remaining results were questionable or unsatisfactory [15]. In 2014, the interlaboratory tests were extended to the second characteristic-adhesion after immersion in water. In 2018, during the tenth jubilee edition of the study, three characteristics were measured: initial tensile adhesion strength and tensile adhesion strength after immersion in water and open time [17]. In the tenth edition, sixty-seven laboratories from 25 European countries and Asia participated in tests. Overall, $94 \%$ of the obtained test results were qualified as satisfactory $(|z| \leq 2)$ under EN ISO/IEC 17043. One of the project's objectives was to show that the constant participation in laboratories' proficiency testing programs improves the quality of tests. In this respect, the study's organizers achieved the intended goal.

In the aspect of meeting the standard requirements by cementitious CTAs, it is worth mentioning the research on the effect of seasoning water on the results of adhesion strength tests [18]. Here, the samples of cementitious CTAs were stored in three types of water: distilled water $(\mathrm{pH}=7.09$, specific conductance: $0.040 \mathrm{mS} / \mathrm{cm})$, tap water $(\mathrm{pH}=8.25$, specific conductance: $0.805 \mathrm{mS} / \mathrm{cm}$ ) and treated tap water $(\mathrm{pH}=8.63$, specific conductance: $1.228 \mathrm{mS} / \mathrm{cm})$. It was found that the origin and type of water used to season the samples greatly influenced the adhesion strength of adhesives. The samples stored in distilled water were characterized by higher adhesion strength than those stored in tap water or softened tap water. In some cases, the difference between the test results was so significant that it determined the compliance with the standard requirements by cementitious adhesives. The adhesion of the cementitious adhesive to tiles is determined in the following system: concrete substrate-adhesive-ceramic tile. Properties of ceramic tiles approved for use during adhesion tests are specified in the standards referred to the given test method in EN 12004. However, not all parameters characterized by ceramic tiles used for testing the adhesion strength of cementitious CTAs are specified. Niziurska assessed the influence of the chemical composition and surface structure of ceramic tiles on the tensile adhesion strength of adhesives to tiles [19]. The results obtained in the tests confirm the influence of the quality of auxiliary materials (ceramic tiles) used in the tests on the compliance with the threshold requirements by the tested tile adhesives.

Many critical comments are made in connection with the adoption in EN 12004 of the adhesion strength determination determined by determining the tensile strength (vertical force) and not the parallel shear force as crucial for the classification of cementitious CTAs $[13,20]$. Shear stresses in the 
substrate-cementitious adhesive-ceramic cladding system may arise due to thermal expansion of the ceramic cladding (e.g., on balconies or terraces) or as a result of subsoil contraction (e.g., fresh concrete or unsealed cement floor). Unfortunately, the shear strength measurements are quite complicated as opposed to the relatively simple tensile strength measurements. For this reason, the shear strength of cementitious tile adhesives is not ordinarily determined. Recently, Fritze and Feichtner described a new test method in which a tile adhesive's tensile strength was determined after a sample was subjected to a controlled shear [20]. In the authors' opinion, the research method proposed by them corresponds well to the real effects that the cementitious CTAs are subjected to under operating conditions. Similarly to other experimental tests, the determination of the tensile adhesion strength is characterized by the dispersion of the obtained results [21-23].

In this study, cementitious CTAs commissioned by market surveillance authorities in 2016-2019 in Poland were analyzed. The commissioning by the construction supervision authorities' tests was to check the correctness of AVCP made by adhesives manufacturers. The obtained results can be analyzed in various dimensions. The first, obviously, is whether or not the product meets the final product's requirements and whether the manufacturer has made the correct AVCP. Another dimension is, by showing the results of the tested samples, determining the quality of products, presenting a picture of the market. The test results show how the conditioning conditions affect the fulfillment of the acceptance criteria for ceramic tiles adhesives; in other words, what conditioning conditions (corresponding to the future exploitation conditions) are the most difficult.

\section{Materials and Methods}

In this article, the test results of 129 cementitious adhesives for ceramic tiles produced by various manufacturers were analyzed. Construction supervision authorities commissioned tests to verify the correctness of the AVCP of cementitious CTAs made by manufacturers before putting them on the Polish market. The products under study were collected by construction supervision authorities from the market, i.e., from DIY stores, from traditional building materials stores. The tests were carried out in three laboratories notified in the scope of the EN 12004 standard. In principle, the obtained results of tests of samples of construction products (together with reports from tests performed by laboratories notified in the appropriate scope) were systematically published on the website of the General Office of Building Control (GUNB). They are widely available through open access [24]. Table 2 presents data on the number of tests performed for ceramic tiles adhesives in 2016-2019.

Table 2. The number of tests of cementitious CTAs carried out by notified laboratories in the scope of EN 12004, commissioned by construction supervision authorities in 2016-2019 in Poland [24].

\begin{tabular}{ccccc}
\hline Year & $\begin{array}{c}\text { No. of CTA } \\
\text { Samples } \\
\text { Taken for Inspection }\end{array}$ & $\begin{array}{c}\text { No. of CTA } \\
\text { Producers } \\
\text { Controlled }\end{array}$ & $\begin{array}{c}\text { Max. no. of CTA } \\
\text { Samples Tested from } \\
\text { One Producer }\end{array}$ & $\begin{array}{c}\text { No. of CTA } \\
\text { Samples Analyzed } \\
\text { (This Work) }\end{array}$ \\
\hline 2016 & 23 & 18 & 3 & 22 \\
2017 & 62 & 28 & 9 & 59 \\
2018 & 42 & 19 & 7 & 39 \\
2019 & 13 & 9 & 2 & 129 \\
\hline Total & 140 & 43 & 9 & 9 \\
\hline
\end{tabular}

This work analyzes results obtained for 129 cementitious adhesives for ceramic tiles, marked by manufacturers as $\mathrm{C} 1, \mathrm{C} 1 \mathrm{~T}, \mathrm{C} 1 \mathrm{TE}, \mathrm{C} 2, \mathrm{C} 2 \mathrm{~T}, \mathrm{C} 2 \mathrm{TE}$, and C2TES1, which were commissioned by construction supervision authorities in 2016-2019. The remaining 11 (taken by building supervisory authorities for inspection) were samples of dispersion adhesives or cementitious adhesives classified other than $\mathrm{C} 1$, C1T, C1TE, C2, C2T, C2TE, and C2TES1. 
Tests of samples of cementitious adhesives for ceramic tiles were carried out under the EN 12004 standard requirements in connection with those declared by manufactures AVCP, using the test methods described in EN 1348:2007 [25].

Table 3 shows the test number of initial tensile adhesion strength, tensile adhesion strength after water immersion, tensile adhesion strength after heat ageing and tensile adhesion strength after freeze-thaw cycles, broken down into the following cementitious adhesive for ceramic tiles: $\mathrm{C} 1, \mathrm{C} 1 \mathrm{~T}$, C1TE, C2, C2T, C2TE, and C2TES1.

Table 3. The number of tensile adhesion strength tests performed under the EN 12004 requirements.

\begin{tabular}{|c|c|c|c|c|}
\hline \multirow[b]{2}{*}{ CTA Class } & \multicolumn{4}{|c|}{ No. of Tensile Adhesion Strength Test Performed } \\
\hline & Initial & $\begin{array}{l}\text { After Immersion } \\
\text { in Water }\end{array}$ & After Heat Ageing & $\begin{array}{c}\text { After Freeze-Thaw } \\
\text { Cycles }\end{array}$ \\
\hline $\mathrm{C} 1$ & 19 & 20 & 14 & 12 \\
\hline $\mathrm{C} 1 \mathrm{~T}$ & 27 & 27 & 24 & 24 \\
\hline C1TE & 16 & 15 & 16 & 16 \\
\hline $\mathrm{C} 2$ & 8 & 8 & 8 & 8 \\
\hline $\mathrm{C} 2 \mathrm{~T}$ & 8 & 8 & 8 & 8 \\
\hline C2TE & 27 & 27 & 27 & 26 \\
\hline C2TES1 & 22 & 22 & 22 & 22 \\
\hline Total & 127 & 127 & 119 & 116 \\
\hline \multicolumn{5}{|c|}{$\begin{array}{l}\text { C1-normal setting cementitious adhesive, C1T-normal setting cementitious adhesive with reduced slip, } \\
\text { C1TE-normal setting cementitious adhesive with reduced slip and extended open time, C2-improved cementitious } \\
\text { adhesive, C2T-improved cementitious adhesive with reduced slip, C2TE-improved cementitious adhesive with } \\
\text { reduced slip and extended open time, C2TES1-improved deformable cementitious adhesives with reduced } \\
\text { slip and extended open time. The total number of cementitious adhesives samples of } 129 \text { and the number of } \\
\text { samples tested under different measurements conditions (Table 2) differs because not all samples were tested in all } \\
\text { considered conditions. }\end{array}$} \\
\hline
\end{tabular}

The notified laboratory for each determined characteristic (initial tensile adhesion strength, tensile adhesion strength after water immersion, tensile adhesion strength after heat ageing and tensile adhesion strength after freeze-thaw cycles), following EN 1348:2007, calculated the mean value by discarding the values falling outside the range of $\pm 20 \%$ from the mean value.

The uncertainty values of the results given by the laboratories notified in the test reports are the expanded uncertainty (related to the accuracy of the devices used) calculated for the confidence level of approximately $95 \%$ and coverage factor $k=2$, and they do not include the sampling stage.

The uncertainty value could not be assigned directly to the properties of a given tested product because the notified laboratories did not know about the variability of the product population, but only about the sample tested. The test results provided by the notified laboratories refer only to the samples tested by them.

\section{Results}

The samples of 129 cementitious adhesives for ceramic tiles tested in 2016-2019 represent seven types of adhesives: C1, C1T, C1TE, C2, C2T, C2TE, C2TES1. The results of the initial tensile adhesion strength, tensile adhesion strength after water immersion, tensile adhesion strength after heat ageing, and tensile adhesion strength after freeze-thaw cycles obtained for each type are presented in Figures 1-7. 
A

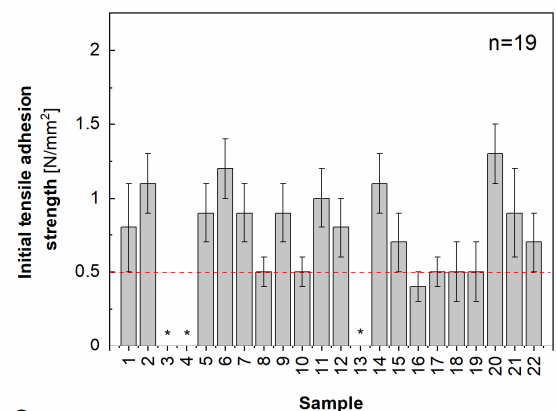

C

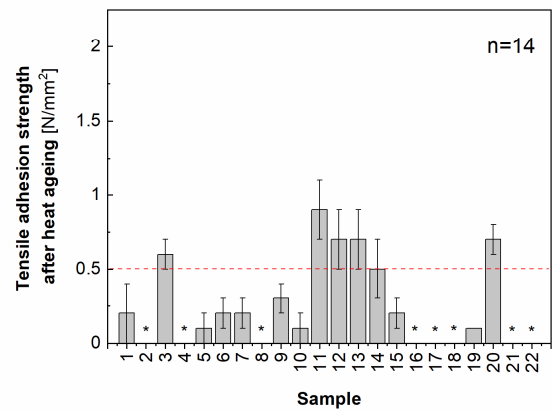

B

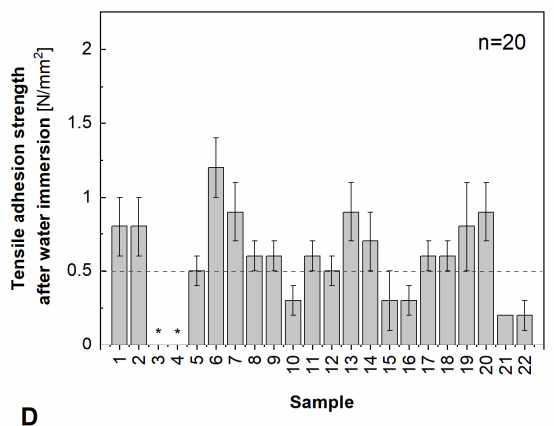

D

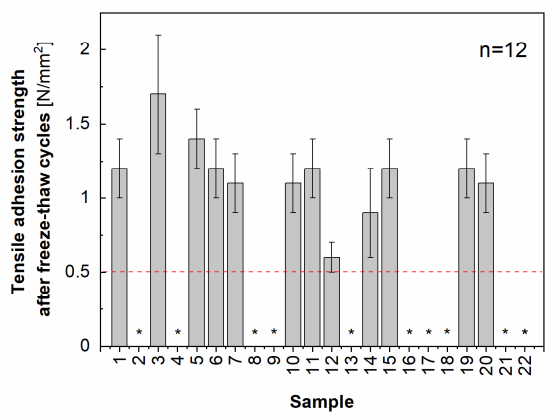

Figure 1. Mean values and measurements uncertainty of initial tensile adhesion strength (A), tensile adhesion strength after water immersion (B), tensile adhesion strength after heat ageing (C), and tensile adhesion strength after freeze-thaw cycles (D) for C1 cementitious adhesives for ceramic tiles. Legend: (-) dashed line represents threshold level acc. to EN 12004, ${ }^{*}$ no data available.

A

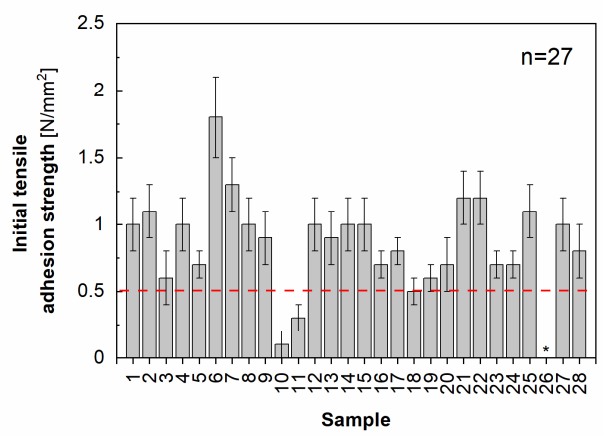

C

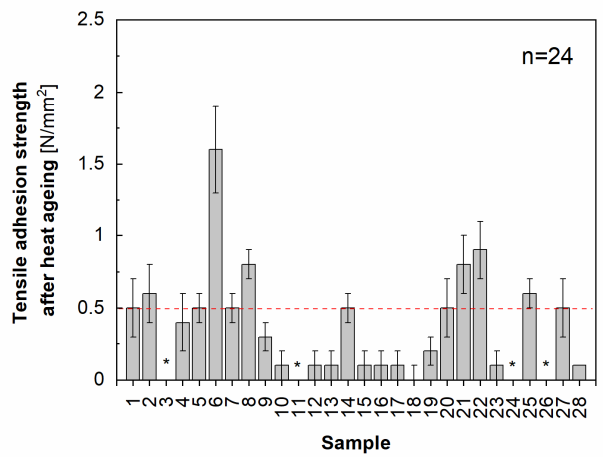

B

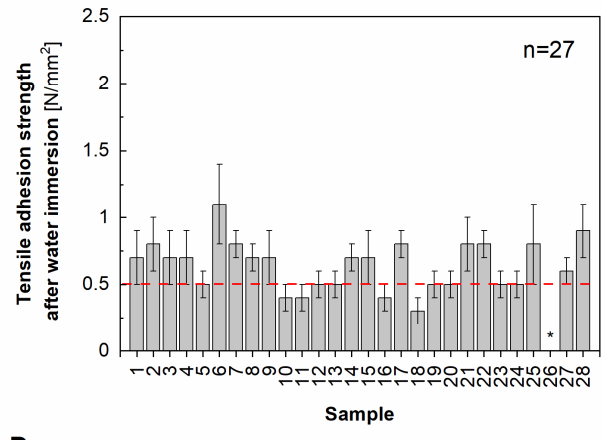

D

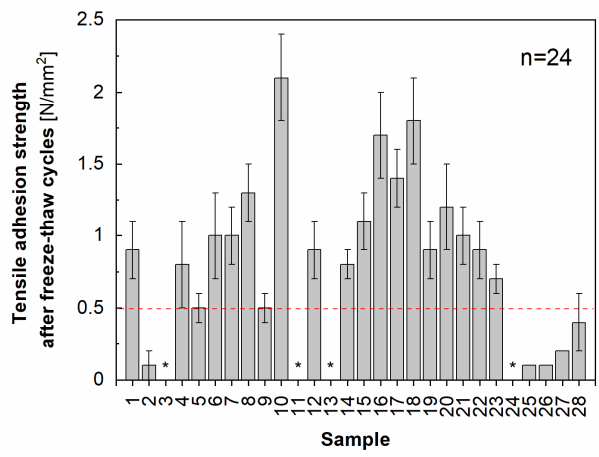

Figure 2. Mean values and measurements uncertainty of initial tensile adhesion strength (A), tensile adhesion strength after water immersion (B), tensile adhesion strength after heat ageing (C), and tensile adhesion strength after freeze-thaw cycles (D) for C1T cementitious adhesives for ceramic tiles. Legend: (-) dashed line represents threshold level acc. to EN 12004, * no data available. 
A

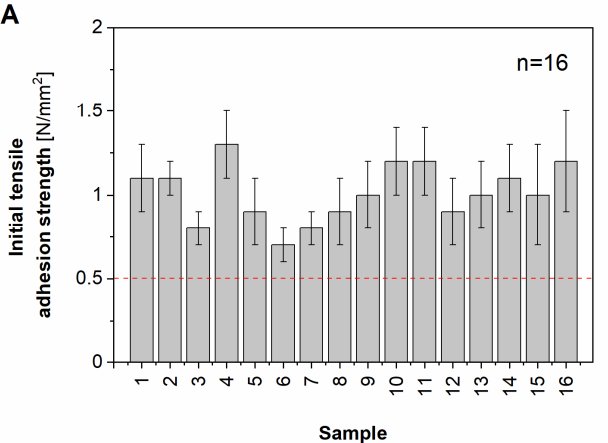

C

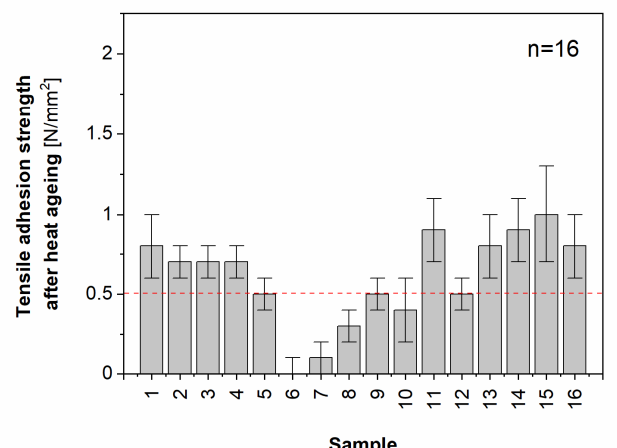

B

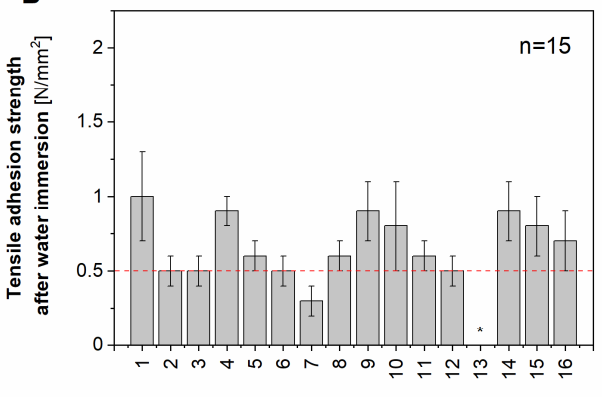

Sample

D

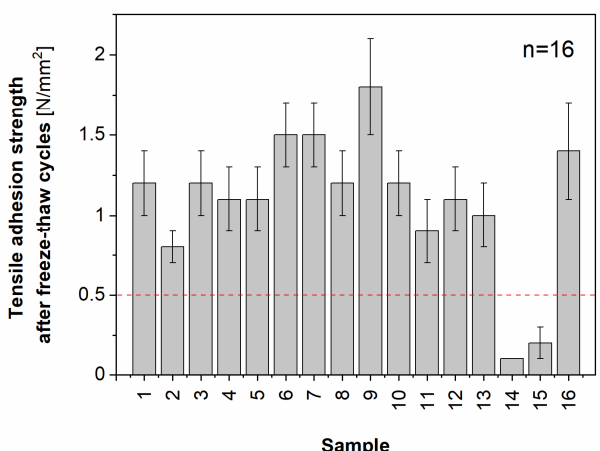

Figure 3. Mean values and measurements uncertainty of initial tensile adhesion strength (A), tensile adhesion strength after water immersion (B), tensile adhesion strength after heat ageing (C), and tensile adhesion strength after freeze-thaw cycles (D) for C1TE cementitious adhesives for ceramic tiles. Legend: (-) dashed line represents threshold level acc. to EN 12004, ${ }^{*}$ no data available.

A

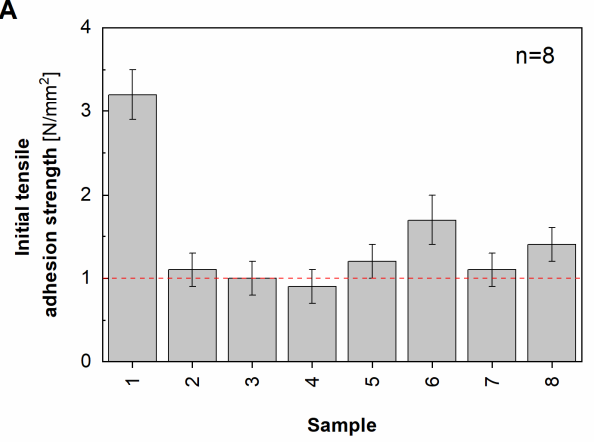

C

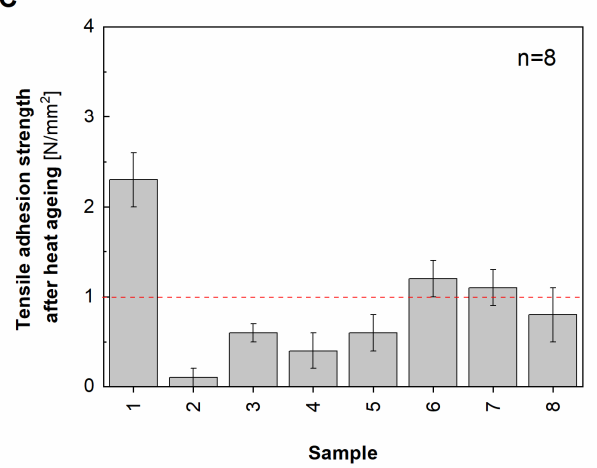

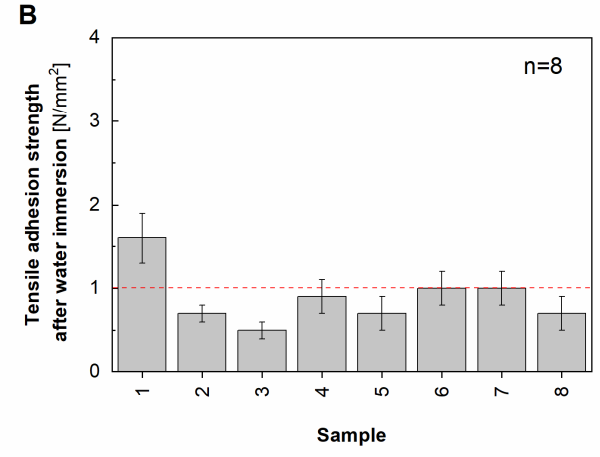

D

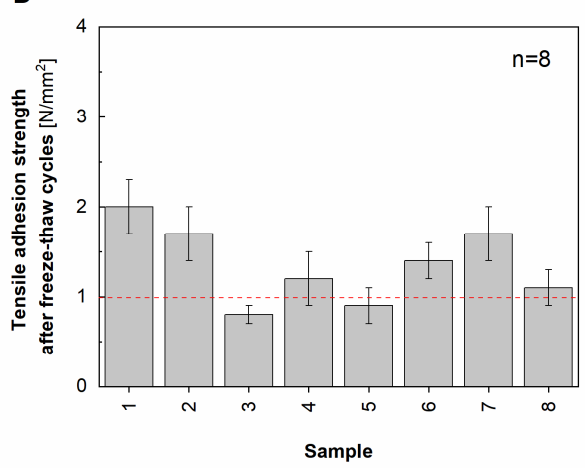

Figure 4. Mean values and measurements uncertainty of initial tensile adhesion strength (A), tensile adhesion strength after water immersion (B), tensile adhesion strength after heat ageing (C), and tensile adhesion strength after freeze-thaw cycles (D) for C2 cementitious adhesives for ceramic tiles. Legend: (-) dashed line represents threshold level acc. to EN 12004, * no data available. 
A

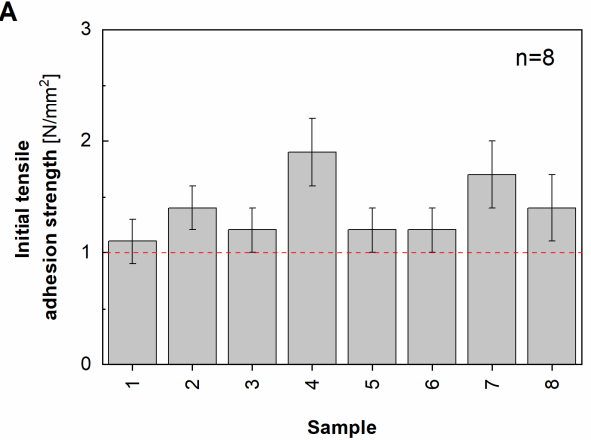

C

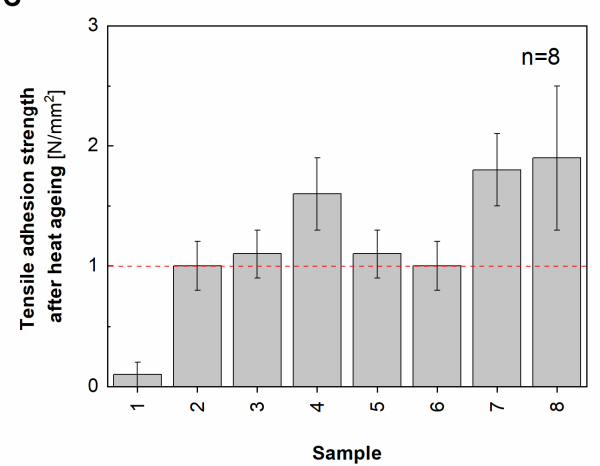

B

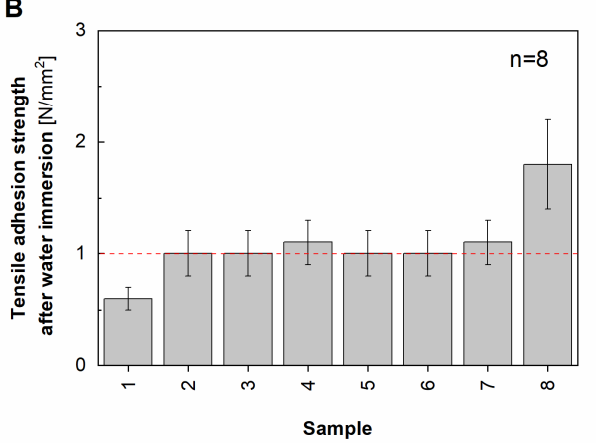

D

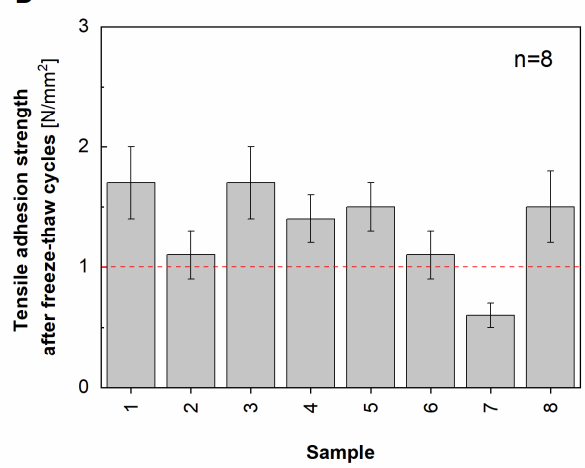

Figure 5. Mean values and measurements uncertainty of initial tensile adhesion strength (A), tensile adhesion strength after water immersion (B), tensile adhesion strength after heat ageing (C), and tensile adhesion strength after freeze-thaw cycles (D) for C2T cementitious adhesives for ceramic tiles. Legend: (-) dashed line represents threshold level acc. to EN 12004, ${ }^{*}$ no data available.

A

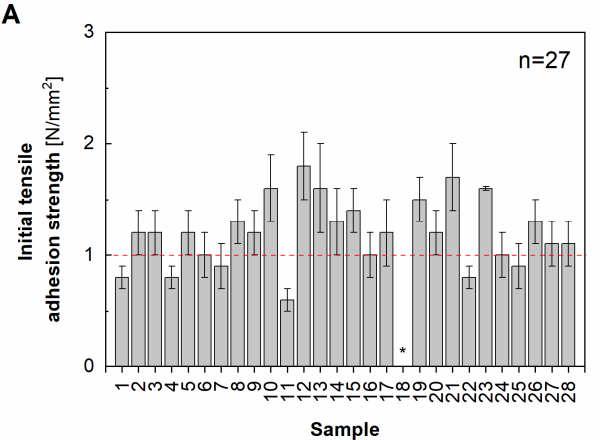

C

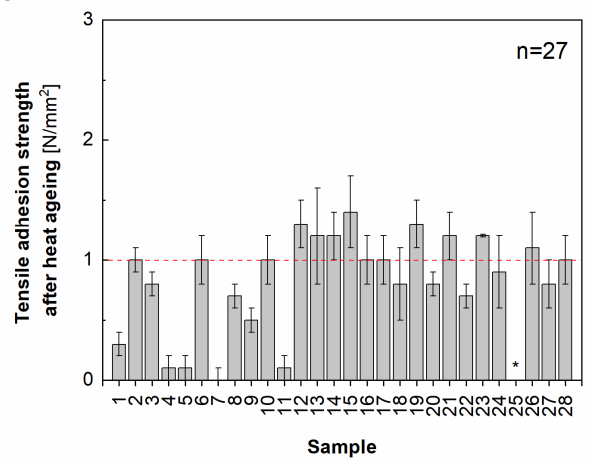

B

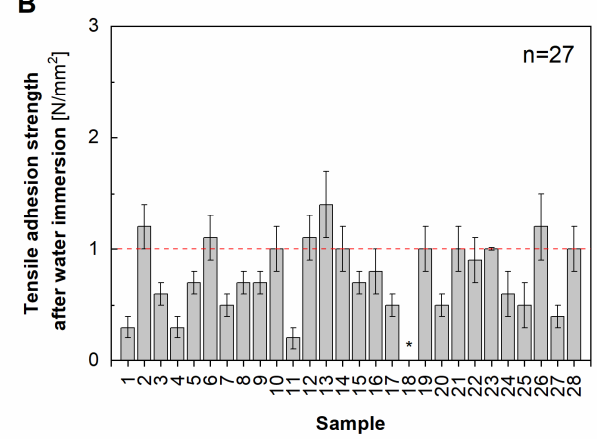

D

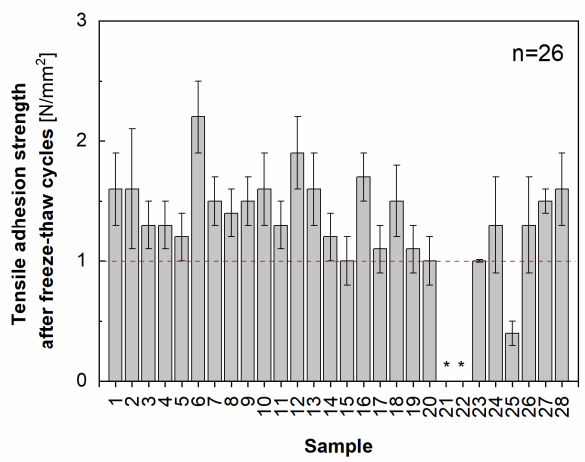

Figure 6. Mean values and measurements uncertainty of initial tensile adhesion strength (A), tensile adhesion strength after water immersion (B), tensile adhesion strength after heat ageing (C), and tensile adhesion strength after freeze-thaw cycles (D) for C2TE cementitious adhesives for ceramic tiles. Legend: (-) dashed line represents threshold level acc. to EN 12004, ${ }^{*}$ no data available. 
A

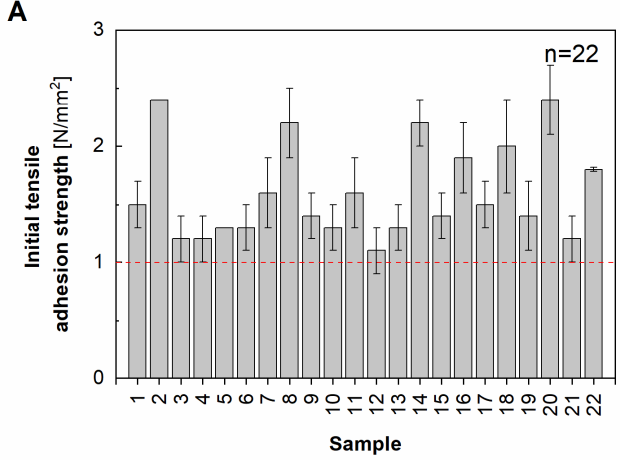

C

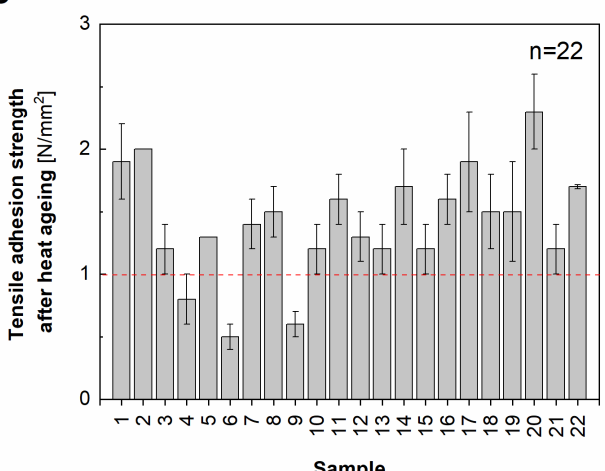

B

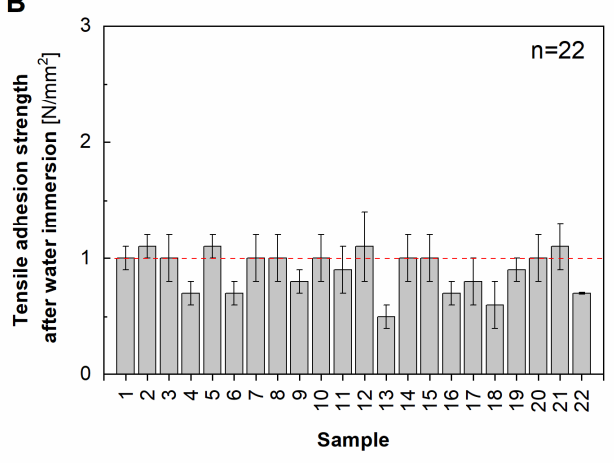

D

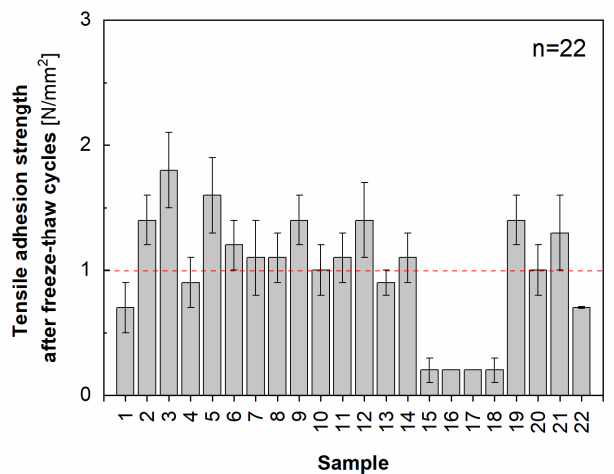

Figure 7. Mean values and measurements uncertainty of initial tensile adhesion strength (A), tensile adhesion strength after water immersion (B), tensile adhesion strength after heat ageing (C), and tensile adhesion strength after freeze-thaw cycles (D) for C2TES1 cementitious adhesives for ceramic tiles. Legend: (-) dashed line represents threshold level acc. to EN 12004, * no data available.

\section{Discussion}

At the beginning of the considerations on the results of the analysis of cementitious adhesives for ceramic tiles, performed in notified laboratories at the request of construction supervision authorities, it is worth noting that the final product conformity assessment is performed using the simple acceptance principle. This means that the product is considered compliant/non-compliant with the obtained test result if this result (without taking into account the variability resulting from the measurement uncertainty) meets the requirements.

There is one more critical issue at the beginning of considering the results of laboratory tests ordered by construction supervision authorities. Considering how complicated the adhesion measurement is and how many factors are not precisely defined in the measurement method, there is a distinct possibility of a dispute between the manufacturer and the construction supervision authority.

Figure 8 shows the percentage of cementitious $\mathrm{C} 1, \mathrm{C} 1 \mathrm{~T}$, and C1TE adhesives that met/did not achieve the minimum tensile adhesion strength of $0.5 \mathrm{~N} / \mathrm{mm}^{2}$ required by EN 12004 for four different conditioning methods. 

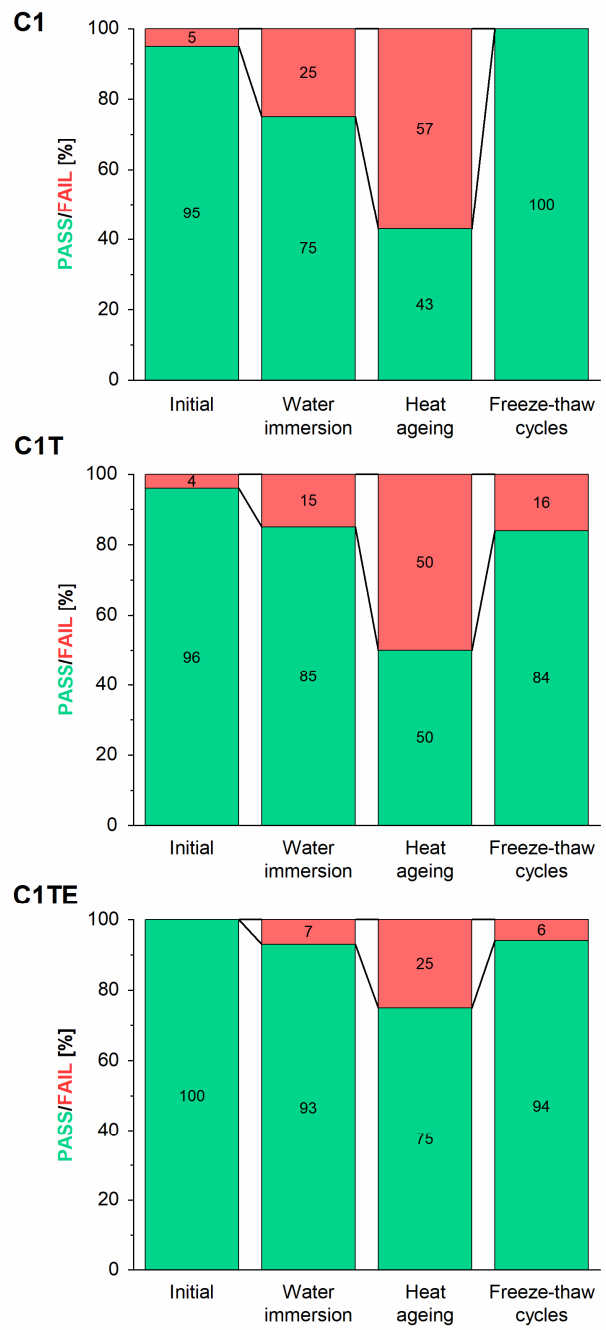

Figure 8. Percentage of cementitious adhesives for ceramic tiles type $\mathrm{C} 1, \mathrm{C} 1 \mathrm{~T}$, and C1TE, which met/did not meet the criterion of tensile adhesion strength of not less than $0.5 \mathrm{~N} / \mathrm{mm}^{2}$ (under different environmental conditions).

In the case of cementitious adhesives of types $\mathrm{C} 1, \mathrm{C} 1 \mathrm{~T}$, and $\mathrm{C} 1 \mathrm{TE}$, most samples did not meet the required tensile adhesion criterion of not less than $0.5 \mathrm{~N} / \mathrm{mm}^{2}$ after thermal ageing $(57 \%, 50 \%$, and $25 \%$, respectively). The required adhesion of not less than $0.5 \mathrm{~N} / \mathrm{mm}^{2}$ after immersion in water was not met by $25 \%$ of cementitious adhesives type C1, $15 \%$ of $\mathrm{C} 1 \mathrm{~T}$, and $7 \%$ of C1TE. After determining the initial tensile adhesion strength and adhesion after the freeze-thaw cycles, a smaller share of adhesives not meeting the requirements of $0.5 \mathrm{~N} / \mathrm{mm}^{2}$ was observed. In the case of the determination of initial tensile adhesion strength, all 16 tested samples of C1TE adhesives met the adhesion criterion of not less than $0.5 \mathrm{~N} / \mathrm{mm}^{2}$. All 12 samples of $\mathrm{C} 1$ adhesives achieved the required value of at least $0.5 \mathrm{~N} / \mathrm{mm}^{2}$ adhesion after the freeze-thaw cycles.

Figure 9 shows the percentage of cementitious adhesives for ceramic tiles type C2, C2T, C2TE, and C2TES1, which met/did not meet the criterion of tensile adhesion strength not less than $1.0 \mathrm{~N} / \mathrm{mm}^{2}$ in various conditioning conditions before the measurement. 
C2
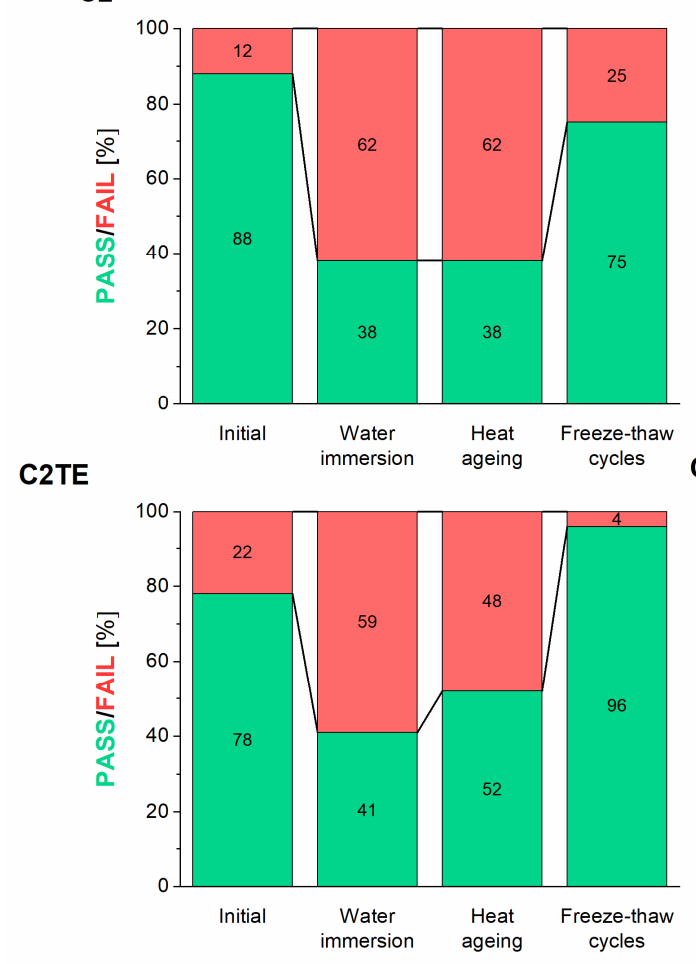

C2T
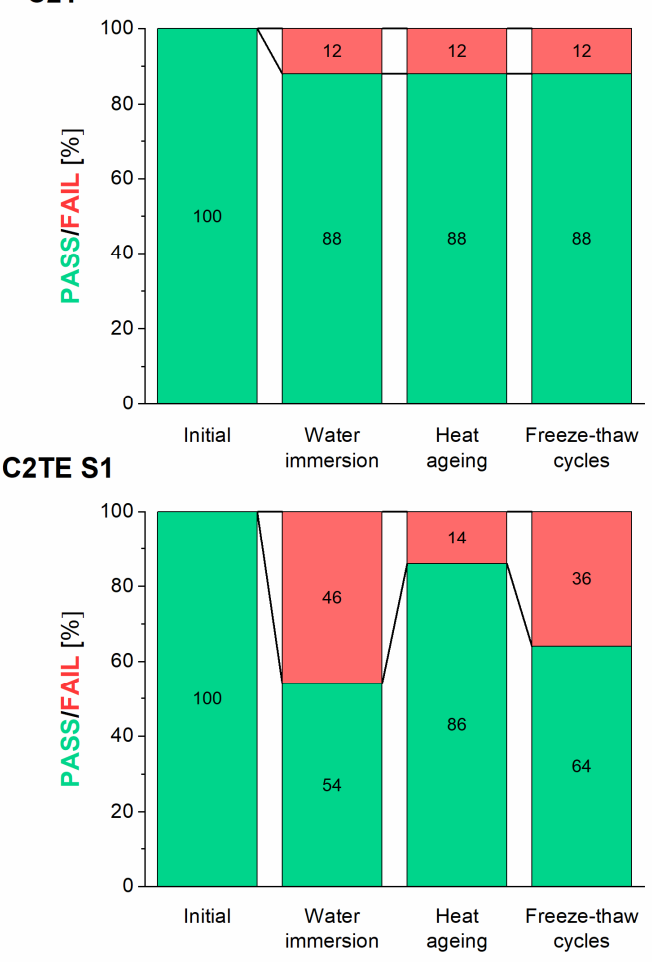

Figure 9. Percentage of cementitious adhesives for ceramic tiles type C2, C2T, C2TE, and C2TES1, which met/did not meet the criterion of tensile adhesion strength not lower than $1.0 \mathrm{~N} / \mathrm{mm}^{2}$ in various conditioning conditions before the measurement.

At the beginning of the discussion of the results obtained for the class's adhesives with increased parameters (C2), it is necessary to note that in the case of cementitious adhesives of C2 and C2T type, the sample population was small. In both cases, it was only $n=8$. Such a small abundance of the examined sample may indicate an incomplete overview of the situation. Thus, the obtained results may not be fully representative.

The largest share of C2, C2T, C2TE, and C2TES1 cementitious adhesives which do not meet the criterion of tensile adhesion strength not less than $1.0 \mathrm{~N} / \mathrm{mm}^{2}$ was observed for samples stored in water: $62 \%$ for $\mathrm{C} 2,59 \%$ for C2TE, $46 \%$ for C2TES1 and $12 \%$ for C2T. After determining the adhesion of cementitious adhesives after immersion in water, the measurement conditions with the largest share of samples not meeting the $1.0 \mathrm{~N} / \mathrm{mm}^{2}$ criterion are the measurement of the tensile adhesion strength after thermal ageing. In the case of thermal ageing, a $62 \%$ share of samples not meeting the requirements for $\mathrm{C} 2$ adhesives was observed, and a $48 \%$ share for $\mathrm{C} 2 \mathrm{TE}$ adhesives. For the other two types of cementitious adhesives, i.e., C2TES1 and C2T, respectively, $14 \%$ and $12 \%$ of products not meeting the criterion of adhesion of not less than $1.0 \mathrm{~N} / \mathrm{mm}^{2}$ were observed. In the case of adhesion measurements after freeze-thaw cycles, the share of products not meeting the adhesion requirement of at least $1.0 \mathrm{~N} / \mathrm{mm}^{2}$ was $36 \%$ for C2TES1 type, $25 \%$ for C2 adhesive, $12 \%$ C2T and only $4 \%$ for C2TE type. For C2T and C2TES1 cementitious adhesives, all tested samples met the initial tensile adhesion strength requirements. However, for $\mathrm{C} 2$ and C2TE adhesives, the share of products that fit the requirements for initial adhesion was $88 \%$ and $78 \%$, respectively.

Figure 10 shows the results of the analysis described in this paper. For each of the analyzed types of cementitious adhesive for ceramic tiles, the average value of the results qualified by notified laboratories and construction supervision authorities as meeting the threshold criterion was given, along with the mean square error of the measurements. The analogically calculated values were given for the results classified by notified laboratories and construction supervision authorities as not meeting the threshold value. 
A

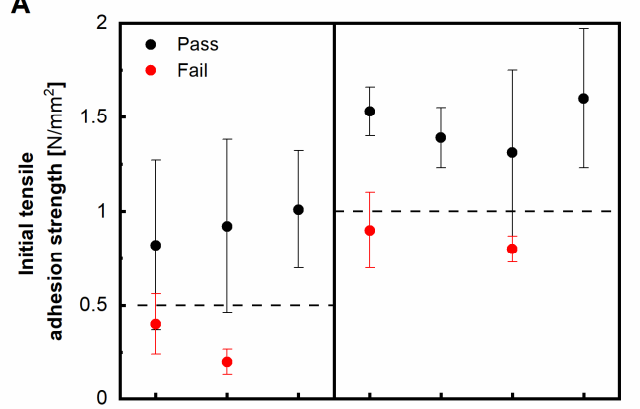

C

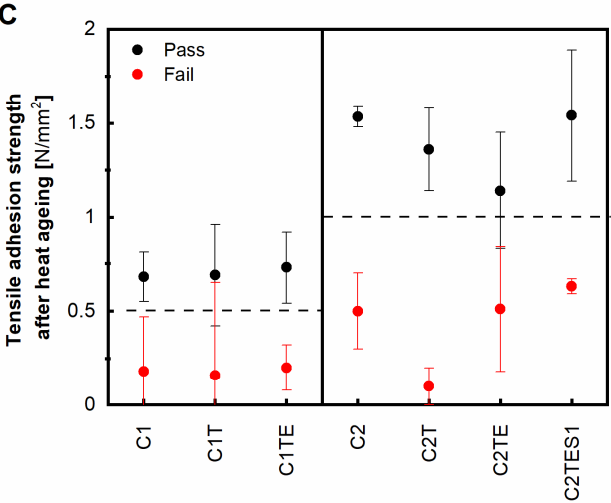

B

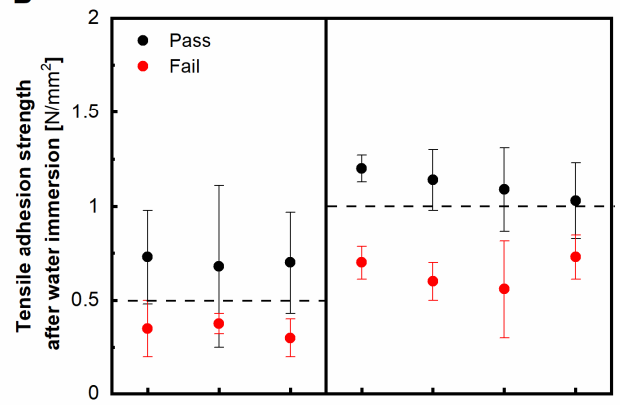

D

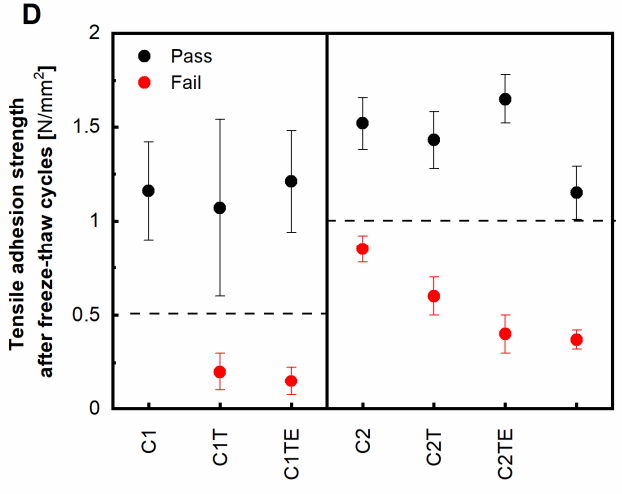

Figure 10. The average value of the tensile adhesion strength results at different conditioning conditions obtained for cementitious adhesives qualified by notified laboratories and construction supervision authorities as meeting/not meeting the threshold criterion (marked by the dashed line), together with the mean square error of measurements.

As shown in Figure 10, in several cases (initial tensile adhesion strength for C1, C1T, and C2TE adhesives, tensile adhesion strength after thermal ageing for $\mathrm{C} 1 \mathrm{~T}$ and $\mathrm{C} 2 \mathrm{TE}$ adhesives, and tensile adhesion strength after water immersion for $\mathrm{C} 2$ adhesive), taking into account the measurements' mean uncertainty would result in a different classification. The same is visible in the figures presenting the test results, e.g., in Figure 2, sample no. 4 (after thermal ageing), and sample no. 28 (after freeze-thaw cycles), in Figure 4, sample no. 4 (after thermal ageing and freeze-thaw cycles), and sample no. 5 (initial tensile adhesion strength), in Figure 6 samples no. 7 and 25 (initial tensile adhesion strength), and sample 22 (after immersion in water). Some of the tested products found to be non-compliant would become compliant products. On the other hand, one can observe a vast number of measurements that are equal to the threshold level with the $20 \%$ uncertainty. This means that with a certain probability they can or cannot meet the criteria of the EN 12004 standard. Due to the complexity of the tensile adhesion strength measurements, the influence of the concrete slab, ceramic tiles, or even the water used for tests, neglecting the uncertainty of measurements may distort the real picture.

The analysis of the results of adhesion tests of 129 cementitious adhesives for ceramic tiles commissioned by the construction supervision authorities in 2016-2019 showed that:

- in the case of adhesives for which the compliance criterion is the adhesion value of at least $0.5 \mathrm{~N} / \mathrm{mm}^{2}$, most products did not meet the requirements for adhesion after thermal ageing. For $\mathrm{C} 1$ adhesives, $57 \%$ did not meet the criteria, slightly less than $50 \%$ for $\mathrm{C} 1 \mathrm{~T}$ adhesives, and $25 \%$ for C1TE adhesives,

- all tested C1TE adhesives met the initial tensile adhesion strength requirement,

- all tested $\mathrm{C} 1$ adhesives met the threshold requirement of $0.5 \mathrm{~N} / \mathrm{mm}^{2}$ in the case of testing the adhesion after freeze-thaw cycles,

- all C2T and C2TES1 adhesives met the threshold requirement of $1.0 \mathrm{~N} / \mathrm{mm}^{2}$ for the initial tensile adhesion determination, 
- among the tested C2 adhesives, as many as $62 \%$ did not meet the criteria for determining adhesion after immersion in water and thermal ageing, $12 \%$ did not meet the requirements for initial adhesion, and $25 \%$ in the case of determining tensile adhesion strength after freeze-thaw cycles,

- the largest share (62\%) of non-conforming products was observed after immersion in water for $\mathrm{C} 2$ adhesives, $59 \%$ for C2TE, $46 \%$ for C2TES1, and $12 \%$ for C2T.

\section{Conclusions}

For cementitious adhesives for ceramic tiles of class/type $\mathrm{C} 1$ (minimum tensile adhesion strength $0.5 \mathrm{~N} / \mathrm{mm}^{2}$ ) and C2 (minimum tensile adhesion strength $1.0 \mathrm{~N} / \mathrm{mm}^{2}$ ), most samples failed to meet this requirement after immersion in water and after thermal ageing.

Due to the use by notified laboratories and the construction supervision authority in Poland, when assessing the compliance of the results with the criteria of the simple acceptance rule, some products were considered non-compliant. Taking into account that the measurement uncertainty would change this classification, in a few cases, products found to be non-compliant would become compliant products.

Discussing the issue of verification, previously performed by the AVCP manufacturer, and currently by the construction supervision authorities in Poland, one should remember the complexity of measuring adhesion defined as tensile strength, including the reproducibility of results, and the influence of various factors on the test result described in the introduction to the article.

Considering the complexity of the AVCP, the results presented in this article can be the basis for the possible verification of legal requirements for the control of a construction product in Poland.

Finally, it is also worth noting Polish construction supervision activities in a broader aspect-market surveillance activities in the European Union. Most EU countries do not conduct such extensive testing of samples taken from the market. In Poland, the results of research commissioned by construction supervision authorities are widely available to everyone, as required by Polish regulations [4]. The General Office of Building Control (GUNB) is required to publish both positive and negative test results, including the manufacturers' names. If the product does not meet the declared characteristics, the manufacturers are charged with the tests performed in notified laboratories. In addition, they must destroy or withdraw the contested products from the market.

Author Contributions: Conceptualization, J.M.; methodology, M.Ł., B.M., and J.M.; validation, M.Ł., and B.M.; formal analysis, M.Ł., and B.M.; investigation, M.Ł., B.M., and J.M.; resources, M.Ł.; data curation, M.Ł., and B.M.; writing-original draft preparation, J.M.; writing-review and editing, B.M., and J.M.; visualization, B.M.; supervision, J.M. All authors have read and agreed to the published version of the manuscript.

Funding: J.M. was partially supported by the Smart Growth Operational Programme 2014-2020 (Project number POIR.02.01.00-00-0350/16).

Conflicts of Interest: The authors declare no conflict of interest.

\section{References}

1. Regulation (EU) No. 305/2011 of the European Parliament and of the Council. Available online: https: //eur-lex.europa.eu/legal-content/EN/TXT/?uri=CELEX:32011R0305 (accessed on 26 July 2020).

2. Regulation (EC) No. 765/2008 of the European Parliament and the Council. Available online: https: //eur-lex.europa.eu/legal-content/EN/TXT/?uri=celex\%3A32008R0765 (accessed on 30 July 2020).

3. Article 88a.1.2 and Article 84.1.1, Ustawa Prawo Budowlane. Available online: https://isap.sejm.gov.pl/isap. nsf/DocDetails.xsp?id=WDU19940890414 (accessed on 30 July 2020).

4. Ustawa o Wyrobach Budowalnych. Available online: http://isap.sejm.gov.pl/isap.nsf/DocDetails.xsp?id= WDU20040920881 (accessed on 2 August 2020).

5. The Value of Building Control. Available online: https://www.cebc.eu/public-current-reports/ (accessed on 2 August 2020).

6. Baraldi, L. World production, and consumption of ceramic tiles. Ceram. World Rev. 2019, 30, 48-63. 
7. European Committee for Standardization (CEN). EN 12004:2001 Adhesives for Tiles-Definitions and Specifications; European Committee for Standardization (CEN): Brussels, Belgium, 2001.

8. Kulesza, M.; Michalak, J. Zmiany w ocenie i weryfikacji stałości właściwości użytkowych cementowych zapraw klejacych do płytek ceramicznych w ostatnim trzydziestoleciu (Changes in assessment and verification of constancy of performance of cementitious ceramic tiles adhesives over the last thirty years). Mater. Bud. 2020, 5, 2-6.

9. European Commission. Summary of References of Harmonized Standards Published in the Official Journal-Regulation (EU) No305/2011 of the European Parliament and of the Council of 9 March 2011 Laying Down Harmonized Conditions for the Marketing of Construction Products and Repealing Council Directive 89/106/EEC; European Commission: Brussels, Belgium, 2019.

10. European Committee for Standardization (CEN). EN 12004:2007+A1:2012 Adhesives for Tiles—Requirements, Evaluation of Conformity, Classification, and Designation; European Committee for Standardization (CEN): Brussels, Belgium, 2012.

11. European Committee for Standardization (CEN). EN 12004-1:2017 Adhesives for Ceramic Tiles-Part 1: Requirements, Assessment, and Verification of Constancy of Performance, Classification, and Marking; European Committee for Standardization (CEN): Brussels, Belgium, 2017.

12. The Council of European Communities. Council Directive of 21 December 1988 on the approximation of laws, regulations and administrative provisions of the Member States relating to construction products. Off. J. Eur. Communities 1989, 40, 12-26.

13. Felixberger, J.K. Polymer-Modified Thin-Bed Tile Adhesive; Institut De Promocio Ceramica: Castelló, Spain, 2008.

14. European Committee for Standardization (CEN). EN 1323:2007 Adhesives for Tiles—Concrete Slabs for Tests; European Committee for Standardization (CEN): Brussels, Belgium, 2007.

15. Coarna, M.; Guslicov, G.; Stancu, C.; Vlad, C. Interlaboratory test on adhesives for ceramic tiles in the last 5 years. In Proceedings of the 4th International Proficiency Testing Conference, Brasov, Romania, 17-20 September 2013.

16. European Committee for Standardization (CEN). EN ISO/IEC 17043:2010 Conformity Assessment-General Requirements for Proficiency Testing; European Committee for Standardization (CEN): Brussels, Belgium, 2010.

17. Stancu, C. The 10th edition of interlaboratory tests for adhesives for ceramic tiles-An anniversary edition. In Proceedings of the 7th International Proficiency Testing Conference, Oradea, Romania, 10-13 September 2019.

18. Nosal, K.; Niziurska, M.; Wieczorek, M. Wpływ zanieczyszczeń zawartych w wodzie przeznaczonej do sezonowania zapraw klejowych do płytek na ich przyczepność. Prace ICiMB 2015, 23, 61-70.

19. Niziurska, M. Znaczenie właściwości płytek ceramicznych w zapewnieniu trwałości okładzin mocowanych zaprawami cementowymi. Prace ICiMB 2013, 14, 17-26.

20. Fritze, P.; Feichtner, G. Flexibility of CTA Beyond Standards. Qualicer 2018, 1-13.

21. Bonaldo, E.; Barros, J.; Lourenco, P. Bond characterization between concrete substrate and repairing SFRC using pull-off testing. Int. J. Adhes. Adhes. 2005, 25, 463-474. [CrossRef]

22. Czarnecki, L.; Garbacz, A.; Krystosiak, M. On the ultrasonic assessment of adhesion between polymer coating and concrete substrate. J. Cem. Concr. Compos. 2006, 28, 360-369. [CrossRef]

23. Lopes, A.C.; Flores-Colen, I.; Silva, L. Variability of the pull-off technique for adhesion strength evaluation on ceramic tile claddings. J. Adhes. 2015, 91, 768-791. [CrossRef]

24. Główny Urząd Nadzoru Budowlanego (The General Office of Building Control). Wykaz Badań Próbek Wyrobów Budowlanych (List of Tests of Samples of Construction Products). Available online: https: //www.gunb.gov.pl/probki (accessed on 2 August 2020).

25. European Committee for Standardization (CEN). EN 1348:2007 Adhesives for Tiles-Determination of Tensile Adhesion Strength for Cementitious Adhesives; European Committee for Standardization (CEN): Brussels, Belgium, 2007.

(C) 2020 by the authors. Licensee MDPI, Basel, Switzerland. This article is an open access article distributed under the terms and conditions of the Creative Commons Attribution (CC BY) license (http://creativecommons.org/licenses/by/4.0/). 